\title{
Study of the Application of iPad-based Digital Learning Games in English Game Teaching in the Primary School
}

\author{
http://dx.doi.org/10.3991/ijoe.v11i9.5070 \\ Liu Junling ${ }^{1}$, Zhang Yawen ${ }^{2}$ \\ ${ }^{1}$ Changji University, Changji, China \\ 2 Xinjiang Normal University, Urumqi, China
}

\begin{abstract}
Game teaching can promote children's cognitive development, emotional development and social participation. This paper bases its analysis on features digital learning English games and feasibility of such games in English game teaching, and proposes an iPad-based twodimensional target system for game teaching, and layout for teaching plan and teaching practice. English game teaching in Grade 3 is taken as an example where setting deployment, resource synchronization, skill training and class application are described in detail aided with case study. Finally, application effect and common problems are identified to provide reference for further study.
\end{abstract}

Index Terms-Digital learning games, iPad, Teaching application.

\section{INTRODUCTION}

With the advancement of science and technology, iPad has been widely applied to elementary education and teaching. Two forms of application have taken shape. One is the design, development and application of e-Textbook on iPad, and the other is educational games and subject tools on iPad. Considering the fact that there is still short of systematic e-Textbooks for all subjects and all stages of education, e-Textbook teaching based on iPad is far from mature and poses high demand on its realization, such as coordination between the professional design team, development team and production team. Generally speaking, the design and development of e-Textbook ask for human, financial and material support. Whereas, educational games and subject tools facing all ages and involving all subjects are popular among elementary school students, given that they are interesting and instructive. Thus, they become the primary digital learning resources for elementary education and teaching. But currently, there are many misunderstanding or mistakes about enjoying digital learning games on iPad. For example, teachers are not restrained from traditional teaching concepts, and teacher-oriented approach is still dominant. Class management is the biggest concern of teacher. Such concern not only affects teaching efficiency, but also distorts the principle of "combining education with recreation". To address such problems, this paper takes English game teaching in Grade 3 as an example to study the application of iPad-based digital learning games to teaching.

\section{Digital learning games on iPad}

App Store on the iPad contains abundant digital learning resources for all subjects and all ages, making it a good digital support for teaching reform of elementary education.

\section{A. Common iPad-based digital learning games for English teaching in elementary school}

There are two forms of digital learning games suitable for elementary school students to learn English. One is educational game and the other is subject tool. Common educational games and subject tools are shown in Table 1.

TABLE I.

COMMON IPAD-BASED DIGITAL LEARNING GAMES FOR ENGLISH TEACHING IN ELEMENTARY SCHOOL

\begin{tabular}{|c|c|c|c|}
\hline Educational games & Introduction & Subject tools & Introduction \\
\hline i Ji Li Gua La & Baby's English Partner for Primary English & ${ }^{2}=\frac{2}{3}$ Baby Learning English & Help children to learn alphabet \\
\hline Fun English & English Games for Age 3-10 & Words in Pictures & Help children to learn words \\
\hline (3) Magic Kid English & $\begin{array}{l}\text { Learning English through situational dialog, } \\
\text { designed for 6-8 }\end{array}$ & $i^{2}{ }^{2}$ Chicktionary & $\begin{array}{l}\text { A game about grouping letters } \\
\text { or forming words }\end{array}$ \\
\hline Baby Learning Color & A stage game for word reading & WD WeEnglish HD & $\begin{array}{l}\text { English vocabulary, } \\
\text { pronunciation and oral practice }\end{array}$ \\
\hline $\begin{array}{l}\text { Words } \\
\text { Words }\end{array}$ & $\begin{array}{l}\text { General word training for primary school } \\
\text { students }\end{array}$ & $\mathrm{Me}$ & $\begin{array}{l}\text { Look at the picture and speak } \\
\text { English }\end{array}$ \\
\hline English & $\begin{array}{l}\text { Reading materials of primary school English } \\
\text { (PEP Edition) : point and read }\end{array}$ & Rerisye Books & Audio books for children \\
\hline
\end{tabular}




\section{B. Features of iPad-based digital learning games for English teaching in elementary school}

(1) Openness of game resources

Any one can publish his own works on iPad through App Store. The openness of game resources makes it possible to update excellent games for different subjects.

(2) Outstanding teaching style

App Store can provide various subject tools and educational games, such as English pronunciation, word recognition, listening and speaking, combinatorial game, sentence training, situation application, etc. These games target at different ages and different subjects. Thus, they can be well combined with teaching goals and facilitate the combination of teaching and learning in various forms, such as listening, speaking, reading, writing, acting, singing and performing.

(3) Supporting human-computer interaction experience

iPad allows for full-screen touch and supports humancomputer interaction experience. Digital learning games for English teaching in elementary school are presented in rich-media which allows users to mobilize visual, sound and touch sense to interact with the computer and create necessary condition for students' intelligent development.

\section{Feasibility of applying iPad-based digital learning games to English teaching in elementary school}

The newly released English Curriculum Standards of Compulsory Education (hereinafter refer to as "curriculum standard") proposed that English courses in elementary education and learning aim at using various teaching resources such as video, TV, books and magazines and internet to expand channels of learning and applying English. The major task to equip students with fundamental knowledge and basic English skills, including listening, reading, speaking and writing, cultivate comprehensive ability of language application, and nurture students' ability of observation, memory, thinking, imagination and creation.

Consider the English teaching practice in elementary school, though wide application of educational games upholds the thinking of "combining education with recreation", there are flaws to amend. These flaws lay obstacles for English game teaching in elementary school and should be addressed. For example, some games has much blindness in that they are lack of innovation and diversity and the game is too simple to be challenging, which undermines student's engagement. App Store on iPad contains updating educational games and subject tools. Integrated with texts, graphs, videos and animation, these games can provide good human-computer interaction experience and meet the need of teachers and students in form and content of games. Games from App Store are in line with ideal, reform request and direction of curriculum standards and drive the reform of English teaching and learning in elementary school.

III. The application of iPad-based digital learning games to English game teaching in elementary school

\section{A. Teaching design}

1. Teaching goal of iPad-based games

Anderson proposed in Taxonomy of Educational Objectives revised in 2001 that the cognitive process includes memory, understanding, application, analysis, evaluation and creation, ranked from the least complicated one to the most complicated one. This method can help teachers make better actions and set up teaching goals in a scientific way. Therefore, based on Taxonomy of Educational Objectives and with three-dimensional goals for the new curriculum reform in elementary school, the iPad-based two-dimensional target system for game teaching is designed, as shown in Table 1.

TABLE I

DESIGN OF IPAD-BASED TWO-DIMENSIONAL TARGET SYSTEM FOR GAME TEACHING

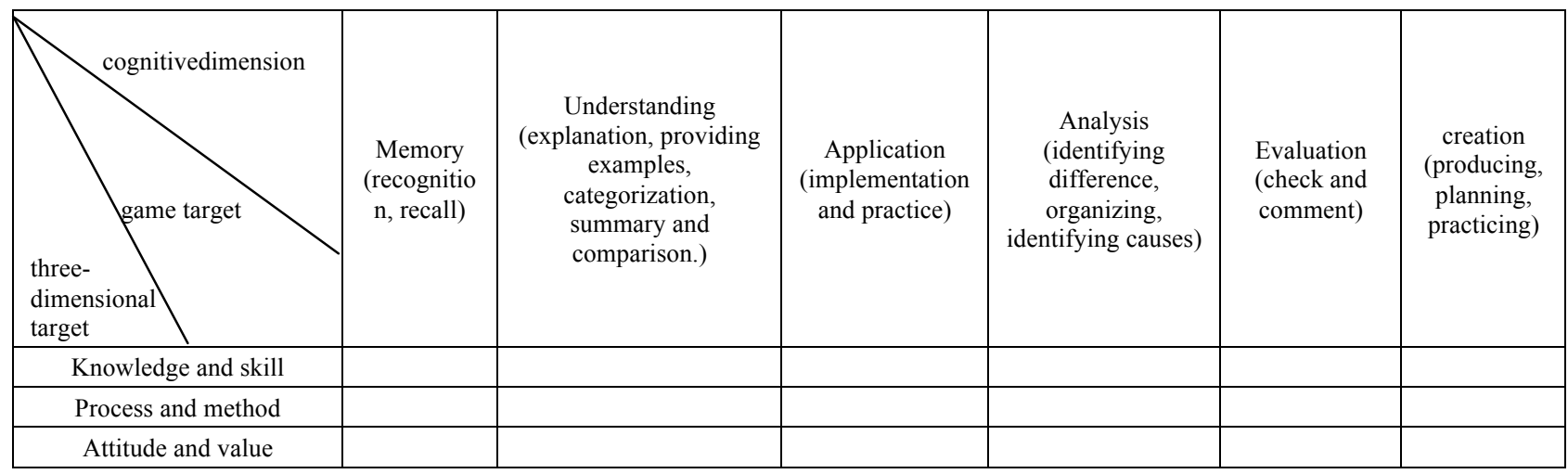

\section{Teaching plan for iPad-based games}

Once the teaching goals are set up, educational games or subject tools on iPad can be selected according to teaching content or knowledge point.
Based on what game to use, questions or tasks are confirmed. While following given rules, games are played under monitoring. Table 2 shows the teaching plan for iPad-based digital learning games 
PAPER

Study of the ApplicAtion of IPAD-BASEd Digital LEARning GAMES In English Game TeACHING IN THE PRIM...

TABLE II.

TEACHING PLAN FOR IPAD-BASED DIGITAL LEARNING GAMES

\begin{tabular}{|c|c|c|c|c|c|}
\hline Target of games & $\begin{array}{c}\text { Knowledge point or } \\
\text { content }\end{array}$ & iPad-based games & Questions or tasks & $\begin{array}{c}\text { Time for } \\
\text { game }\end{array}$ & \begin{tabular}{l} 
Game test \\
\hline Target 1
\end{tabular} \\
\hline$\ldots .$. & & & & & \\
\hline
\end{tabular}

\section{Teaching process for iPad-based games}

Game loops can be designed according to different teaching goals. But it is necessary to clarify the tasks and resources or tools to fulfill the task, which are quite flexible. Table 3 shows the design for teaching practice of iPad-based games.

TABLE III.

DESIGN FOR TEACHING PROCESS OF IPAD-BASED GAMES

\begin{tabular}{|c|c|c|c|}
\hline \multicolumn{2}{|c|}{ Teaching layout } & Resources or tools & Phased mission \\
\hline \multirow{3}{*}{\multicolumn{2}{|c|}{$\begin{array}{l}\text { Connection of old knowledge and new knowledge and their changes } \\
\text { (alternate with iPad-based games) }\end{array}$}} & $\begin{array}{l}\text { iPad-based educational games (or } \\
\text { subject tools) }\end{array}$ & \multirow{3}{*}{$\begin{array}{l}\text { Proposing teaching goals and } \\
\text { tasks }\end{array}$} \\
\hline & & iPad rich-media courseware & \\
\hline & & Traditional teaching games & \\
\hline \multirow{4}{*}{$\begin{array}{c}\text { Learning and internalizing new } \\
\text { knowledge } \\
\text { (alternate with iPad-based } \\
\text { games) }\end{array}$} & Knowledge point 1 & $\begin{array}{c}\text { iPad-based educational games (or } \\
\text { subject tools), student-version } \\
\text { course wares }\end{array}$ & \multirow{5}{*}{$\begin{array}{l}\text { Knowledge learning, summary } \\
\text { and enlargement }\end{array}$} \\
\hline & Knowledge point 2 & iPad rich-media courseware & \\
\hline & Knowledge point 3 & Traditional teaching games & \\
\hline & $\ldots \ldots$ & $\ldots \ldots$ & \\
\hline $\begin{array}{l}\text { Enlarging and practicing new } \\
\text { knowledge } \\
\text { (alternate with iPad-based } \\
\text { games) }\end{array}$ & All knowledge & $\begin{array}{l}\text { iPad-based educational games (or } \\
\text { subject tools) }\end{array}$ & \\
\hline \multicolumn{2}{|c|}{ Summary and test } & IExam or Eclicker test & Comment, analysis and summary \\
\hline
\end{tabular}

\section{B. Teaching application}

1. Setting deployment

(1) Deploy iPad terminals

Initialize settings iPad (eg: iOS initialization, Apple ID registration) and install common software and apps (such as iTunes, iBooks, Keynote, wps).

(2) Deploy wireless device

Based on 802.11n wireless network technology, connect iPad to Wi-Fi and make sure the network request.

(3) Connect iPad with wireless projector

Connect iPad with Apple TV produced by Apple. Inc., so that in the Wi-Fi environment, iPad can be connected to wireless projector (or connect with the projector or through VGA)

2. Resource synchronization

iTunes is a free application deployed on Mac and PC. Batch synchronization can be realized through iTunes in order to make sure that teachers and students share the resources.

\section{Skill training}

The iPad operation training is conduced according to how familiar teachers and students are to information technology. The training includes: iPad human-computer interaction experience (iPad keyboard and Muti-Touch), preference settings (such as brightness and voice of the screen), Apple ID registration and App Store usage, Airplay Wireless Projectors, etc.
4. Class application

Color (PEP Edition) for English teaching in elementary school is taken as an example to account for how to integrate iPad-based educational game into teaching and learning. Details are shown in Table 4.

\section{CONCLUSIONS}

Through teacher comment, iPad test tool, mutual comment and class monitoring, it is found that iPad-based game (digital learning games) can motivate students' interest to learn, help them identify, classify, summarize and use new words and sentences, and encourage them to think deeply about certain phenomenon. In terms of recognition, students can achieve the ability to memorize, understand, use, analyze, evaluate and create, as proposed in Anderson's Taxonomy of Education Objectives. However, some problems present themselves, among which teaching organization and management is a key concern. After a deep analysis, it is found that the root cause is teaching layout. It is easy to create chaos if the content, time and rules of the game are not clear. What's more, if the content of the game, knowledge points and learning goals do not comply with each other, the teaching effect may also be undermined. The application of iPadbased digital learning games should address course content, learning conditions and characteristics of students and be combined with traditional games so that students' eyes would not be worn out and less negative effect would be posed on their health. 
TABLE IV.

CASE STUDY OF THE APPLICATION OF IPAD-BASED GAMES TO ENGLISH TEACHING IN ELEMENTARY SCHOOL

\section{《Color》}

\section{Teaching goal}

\section{Knowledge and skill}

(1) Through the iPad-based game, identify colors and pronouciate words accurately;

(2) Through the iPad-based game, classify colors and summarizethem;

(3) Use new words and sentences to engage in situational dialog.

\section{Process and method}

(1) Through the iPad-based game, test to what degree new words are memorized;

(2) Through the iPad-based game, practice new words and new sentences;

(3) Through the iPad-based tools, test and comment students' learning effect.

3. Attitude and value

(1) Through the iPad-based game, students can feel the change of colors;

(2) Through video and photo-taking tools, show students' works and learning process and motivate them to encourage each other;

(3) Through video displaying, encourage students to think of the fact that colors in life are fading and share their opinions.

\begin{tabular}{|c|c|c|c|c|c|c|c|}
\hline \multicolumn{8}{|c|}{ Teaching plan } \\
\hline \multicolumn{2}{|c|}{ Target of games } & \multirow{2}{*}{$\begin{array}{c}\begin{array}{c}\text { Knowledge point or } \\
\text { content }\end{array} \\
\text { Word }\end{array}$} & \multirow{2}{*}{$\frac{\text { iPad-based games }}{\text { Video, Baby Learning Color }}$} & \multicolumn{2}{|c|}{ Questions or tasks } & Time for game & \multirow{2}{*}{$\begin{array}{c}\text { Game test } \\
\text { Teaching } \\
\text { commenting }\end{array}$} \\
\hline \multirow{3}{*}{$\begin{array}{l}\text { Knowledge } \\
\text { and skill }\end{array}$} & (1) & & & $\begin{array}{r}\text { Ide } \\
\text { pronunc }\end{array}$ & $\begin{array}{l}\text { ntify colors and } \\
\text { iatewords accurately }\end{array}$ & $4 \mathrm{~min}$ & \\
\hline & $(2)$ & Word & Baby Learning Color & & $\begin{array}{l}\text { assify colors and } \\
\text { summarize }\end{array}$ & $2 \mathrm{~min}$ & $\begin{array}{c}\text { Teaching } \\
\text { commenting }\end{array}$ \\
\hline & (3) & Word and sentence & Baby Learning Color -My colors lite & Use v & vord and sentences & $4 \mathrm{~min}$ & $\begin{array}{c}\text { Teaching } \\
\text { commenting }\end{array}$ \\
\hline \multirow{3}{*}{$\begin{array}{l}\text { Process and } \\
\text { method }\end{array}$} & $(1)$ & Word & Baby Learning Color -stage game & & Word test & $3 \mathrm{~min}$ & Game test \\
\hline & (2) & Word and sentence & $\begin{array}{l}\text { Baby Learning Color -Color the } \\
\text { Color, Snow Baby Love Color }\end{array}$ & Draw & $\begin{array}{l}\text { ing and situational } \\
\text { dialogues }\end{array}$ & $4 \mathrm{~min}$ & $\begin{array}{l}\text { Teaching } \\
\text { commenting }\end{array}$ \\
\hline & (3) & Word and sentence & Eclicker & & Effect test & $5 \mathrm{~min}$ & Testing tool \\
\hline \multirow{3}{*}{$\begin{array}{l}\text { Attitude } \\
\text { and value }\end{array}$} & (1) & Change of colors & $\begin{array}{l}\text { Baby Learning Color-Magic Color } \\
\text { Box }\end{array}$ & Exper & $\begin{array}{l}\text { ience the change of } \\
\text { colors }\end{array}$ & $2 \min$ & $\begin{array}{l}\text { Teaching } \\
\text { commenting }\end{array}$ \\
\hline & (2) & Learning process & Video and photo-taking tools & Mutu & tal encouragement & $3 \mathrm{~min}$ & $\begin{array}{l}\text { Teaching } \\
\text { commenting }\end{array}$ \\
\hline & (3) & Emotion elevation & Video & Enc & courage thinking & $3 \min$ & $\begin{array}{l}\text { Teaching } \\
\text { commenting }\end{array}$ \\
\hline \multicolumn{8}{|c|}{ Teaching process } \\
\hline \multicolumn{3}{|c|}{ Teacher activity } & \multicolumn{2}{|l|}{ Digital game resources or tools } & \multicolumn{2}{|c|}{ Student activity } & Schedule \\
\hline \multicolumn{8}{|c|}{ Introduction of new knowledge } \\
\hline \multicolumn{3}{|c|}{$\begin{array}{l}\text { Play the video, raise the question and analyze } \\
\text { the question: How many colors in the video? }\end{array}$} & \multicolumn{2}{|c|}{$\begin{array}{l}\text { Wireless projector, display the video on the } \\
\text { screen_-a cat changing colors }\end{array}$} & \multicolumn{2}{|c|}{ First is $\ldots$, next is .... } & $10: 00-10: 03$ \\
\hline \multicolumn{3}{|c|}{$\begin{array}{l}\text { 1.Memorize new words about colors } \\
\text { 2. Read after the teacher }\end{array}$} & \multicolumn{2}{|c|}{$\begin{array}{l}\text { 1.iPad-based game-Baby Learning Color } \\
\text { (clarify rules of the game) }\end{array}$} & \multicolumn{2}{|c|}{$\begin{array}{l}\text { 1. Word practice on iPad } \\
\text { 2. Read aloud }\end{array}$} & $10: 04-10: 06$ \\
\hline \multicolumn{8}{|c|}{ Learning and internalizing new knowledge } \\
\hline \multicolumn{3}{|c|}{$\begin{array}{l}\text { 1. According to tips in the iPad-based } \\
\text { game-Lion, play while practicing } \\
\text { 2. Summarize the types of colors }\end{array}$} & \multicolumn{2}{|c|}{$\begin{array}{c}\text { 1.iPad-based game - colors } \\
\begin{array}{c}\text { 2. Wireless projector, show various colors on } \\
\text { the screen (teacher courseware) }\end{array}\end{array}$} & \multicolumn{2}{|c|}{$\begin{array}{l}\text { 1. Word practice on iPad } \\
\text { 2. Read aloud }\end{array}$} & $10: 07-10: 10$ \\
\hline \multicolumn{3}{|c|}{ 3. Practice new words } & \multicolumn{2}{|c|}{$\begin{array}{l}\text { 3.iPad-based educational game-Baby } \\
\text { Learning Color }\end{array}$} & \multicolumn{2}{|c|}{ 3. Stage game for words } & $10: 11-10: 12$ \\
\hline $\begin{array}{l}\text { 4. New } \\
\text { It is .... }\end{array}$ & $\begin{array}{l}\text { sente } \\
\ldots(\mathrm{F} \\
\text { (Teac }\end{array}$ & $\begin{array}{l}\text { What color is it? } \\
\text { after the teacher) } \\
\text { comment) }\end{array}$ & $\begin{array}{l}\text { 4. iPad-based game-My colors lite } \\
\text { rules of the game) }\end{array}$ & (Clarify & 4. Read al & & $10: 13-10: 15$ \\
\hline & & & Enlarging and practicing nev & v knowle & dge & & \\
\hline $\begin{array}{l}\text { 1. Dye colo } \\
\text { dialog (pra }\end{array}$ & $\begin{array}{l}\text { rs and } \\
\text { tice } \mathrm{n} \\
\text { 2. } \mathrm{Ch}\end{array}$ & $\begin{array}{l}\text { Irticipate in situational } \\
\text { words and sentences) } \\
\text { ge of color }\end{array}$ & $\begin{array}{l}\text { 1. iPad-based educational game- } \\
\text { Learning Color (Color the Color, Sno } \\
\text { Love Color) } \\
\text { 2. iPad-based educational game-Mag } \\
\text { Box (Clarify rules of the game }\end{array}$ & $\begin{array}{l}\text { Baby } \\
\text { w Baby } \\
\text { ic Color }\end{array}$ & $\begin{array}{r}\text { 1. Dye colors and pa } \\
\text { situational } \mathrm{d} \\
\text { 2. Experience the ma } \\
\text { of color }\end{array}$ & $\begin{array}{l}\text { ticipated in } \\
\text { log } \\
\text { rical change }\end{array}$ & $10: 16-10: 22$ \\
\hline 3. W & ork s & $\mathrm{V}$ and comment & $\begin{array}{l}\text { 3. Wireless projector, show students } \\
\text { on the screen }\end{array}$ & works & $\begin{array}{r}\text { 3. Student's wor } \\
\text { description and mutc }\end{array}$ & $\begin{array}{l}\text { show, } \\
\text { al-comment }\end{array}$ & $10: 23-10: 25$ \\
\hline & & & Summary and tes & & & & \\
\hline 1. Practice & $\begin{array}{r}\text { vords } \\
\text { th }\end{array}$ & $\begin{array}{l}\text { sentences (Read after } \\
\text { eacher) }\end{array}$ & $\begin{array}{l}\text { 1. Wireless projector, show key kno } \\
\text { points }\end{array}$ & wledge & $\begin{array}{l}\text { 1. Read aloud, inc } \\
\text { practice }\end{array}$ & ependent & $10: 26-10: 29$ \\
\hline 2. Han & d out & rcises and lecture & $\begin{array}{l}\text { 2.iPad test tool-Eclicker } \\
\text { (Clarity rules for use })\end{array}$ & & $\begin{array}{r}\text { 2. Log in, answer the } \\
\text { test }\end{array}$ & question and & $10: 30-10: 35$ \\
\hline $\begin{array}{l}\text { 3. Emotion } \\
\text { and becomir } \\
\text { do? (Summa }\end{array}$ & $\begin{array}{l}\text { levat } \\
\text { g dar } \\
\text { ry an }\end{array}$ & $\begin{array}{l}\text { why colors are fading } \\
\text { life? What should we } \\
\text { omment by the teacher) }\end{array}$ & $\begin{array}{l}\text { 3. Wireless projector, show the vide } \\
5^{\text {th }} \text { good advertising creative compet } \\
\text { environment protection }\end{array}$ & $\begin{array}{l}\text { of the } \\
\text { tion for }\end{array}$ & $\begin{array}{r}\text { 3. Watch the view } \\
\text { opinions on how } \\
\text { towards the fact that } \\
\text { are becoming }\end{array}$ & $\begin{array}{l}\text { and share } \\
\text { ne views } \\
\text { olors in life } \\
\text { dark }\end{array}$ & $10: 36-10: 40$ \\
\hline
\end{tabular}


PAPER

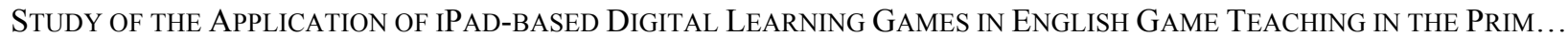

\section{REFERENCES}

[1] Liu Hongxia, Zhao Wei, Duo Shaojun. Study of Design and Practice of Classroom Collaborative Learning Under the Support of Mobile Technology [J]. China Educational Technology, 2013, 06: 86-92.

[2] Liu Fanhua,Yu Huijuan, Tan Fang. Study of E-schoolbag and Education Application [J]. E-education Research, 2013, 01: 73$76+85$.

[3] Yang Xiaohong, Jia Wei. Study of the Construction of Digital Learning Resources Under the Guide of Modern Learning Concept [J]. China Educational Technology, 2013, 03: 84-88+95.

[4] Li Xiaorong. Study of Status Quo, Question and Solution of Digital Learning Resources in Secondary School [D]. Shaanxi Normal Univeristy, 2010.

[5] Sun Yi. The Study of Digital Learning Resources to Design in Physics of Middle School for Developing Higher Order Thinking Skills [D]. Northeast Normal University, 2011.

[6] Wan Liyong. Study of Quality Evaluation of Digital Learning Resources [J]. Modern Education Technology, 2013, 01: 45-49.

[7] Zhou Kejiang, Jiang Hua, Luo Qin, Li Yongfan. Space Model for Digital Learning Resources Application and Information Model Design for Subject Knowledge Ontology Resources Based on ULearning [J]. E-education Research, 2015, 02: 45-49.
[8] Miia Ronimus \& Ulla Richardson. Digital game-based training of early reading skills: overview of the GraphoGame method in a highly transparent orthography Entrenamiento de habilidades de lectura tempranas basado en un juego digital: visión general del método GraphoGame en una ortografía altamente transparente [J]. Estudios de Psicología, 2014, 35(03): 648-661 http://dx.doi.org/10.1080/02109395.2014.974424

\section{AUTHORS}

Liu Junling, Changji Univerisity, Major research directions are mobile study and information technology, Email:164505333@qq.com.

Zhang YaWen, Xinjiang Normal University, Major research directions are digital learning and online education. Email: 87690289@qq.com.

This work was supported in part by Twelfth Five-Year-Plan Science Education Project of Xinjiang Uygur Autonomous Region (Project No: 145017). For Xinjiang teacher education research center key projects funded by the Xinjiang Uygur autonomous region Ordinary university humanities and social science key research base (Project No: XJEDU040515B02). It is also a phased achievement for Twelfth FiveYear-Plan Key Project and a sub-project (KTLX130002) of New Classroom Teaching Research. Submitted 21 September 2015. Published as resubmitted by the authors 20 October 2015 . 